\title{
"Voyage through death/to life upon these shores": the living dead of the Middle Passage
}

\section{Joanne Chassot}

To cite this article: Joanne Chassot (2015) "Voyage through death/to life upon these shores": the living dead of the Middle Passage, Atlantic Studies, 12:1, 90-108, DOI: 10.1080/14788810.2014.993825

To link to this article: http://dx.doi.org/10.1080/14788810.2014.993825

$$
\text { 电 Published online: } 25 \text { Feb } 2015 .
$$

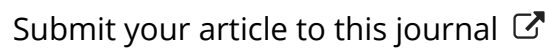

Џلll Article views: 288

Q View related articles $\longleftarrow$

View Crossmark data \ 


\title{
"Voyage through death/to life upon these shores": the living dead of the Middle Passage
}

\author{
Joanne Chassot*
}

\begin{abstract}
While historical studies of the Atlantic slave trade have amply demonstrated the magnitude of slave mortality during the Middle Passage, only recently have they started to examine how the captives might have endured and coped with this traumatic experience. Although it constitutes a major topos in African diasporic culture, the Middle Passage has only occasionally been represented directly and in details in novels and in films. This article examines three recent narratives of the Middle Passage, Fred D'Aguiar's novel Feeding the Ghosts (1998), Guy Deslauriers's film Passage du milieu (2000), and Stephanie Smallwood's historical study Saltwater Slavery: A Middle Passage from Africa to American Diaspora (2007). Beyond their individual poetic, aesthetic, and scholarly qualities, what is most striking about these three texts is that they all use the figure of the living dead in order to explore the captives' experience of the transatlantic journey. If the ghastly quality of the living dead powerfully captures the life-threatening material and physical conditions the captives endured on the voyage, its dual, liminal character also allows D'Aguiar, Deslauriers, and Smallwood to represent the metaphysical, psychological, social, and cultural journey they were forced to undertake. Through their use of the trope of the living dead, these three texts show that if death is indeed a central aspect of the experience of the Middle Passage, it impacts the captives in ways that go well beyond the issue of mortality.
\end{abstract}

Keywords: Middle Passage; living dead; social death; zombi; Fred D'Aguiar; Guy Deslauriers; Stephanie Smallwood

In his poem "Middle Passage," Robert Hayden repeatedly qualifies the Africans' transatlantic journey as a "voyage through death." Historians of the slave trade have amply demonstrated the adequacy of this seeming hyperbole. If they did not drive them to suicide or insurrections that inevitably caused more casualties, the unsanitary conditions of the slave ship's hold often led to sickness and epidemics that killed the captives in large numbers. The hazards of the journey were such that Europeans involved in the trade as captains, sailors, or surgeons commonly referred to the slave ships as "slaughterhouses," "coffins," or "floating tombs." Assessing the actual scale of shipboard mortality was long the main preoccupation of historians of the slave trade. Their contribution to this "numbers game" allowed for a better understanding of the extent, operating processes, as well as demographic and economic consequences of what one of those quantitative studies identified as "one of the least explored aspects of modern economic and social history." Writing in 1978, Herbert S. Klein confidently concluded his examination of the Middle Passage with the belief that if "the individual African experience [...] cannot be

*Email: Joanne.Chassot@unil.ch 
recaptured," a quantitative account at least "helps to define the limits within which that experience took place."4

It is largely in response to such admitted methodological and epistemological limitations that recent historical studies have turned to a more qualitative approach to the subject. In Saltwater Slavery: A Middle Passage from Africa to American Diaspora (2007), African-American historian Stephanie E. Smallwood takes issue with the traditional historiographical approach that has considered shipboard mortality as the key to understanding the experience of the captives and the measure of the horror and trauma it represents in world history. ${ }^{5}$ Tracing the transformative journey from "African captives" through "Atlantic commodities" to "American slaves," her book offers an unprecedented historical account of the subjective experience of the Middle Passage from the slave ship's hold. Although mortality still is a central element in this narrative, what Smallwood is interested in is not the cold facts and numbers but the live experience of the people these facts and numbers long stood for: the issue is not so much how many died and how many lived, but how the Africans dealt with the death of their fellow captives and the prospect of their own death, as well as how they sustained life in the midst of a deathful experience. This new focus on other dimensions of slave mortality sheds a very different light on both life and death and reveals the complex tensions the Middle Passage created between the two.

A similar impulse "to fill in the gaps of an eradicated past and to understand history through personality, through people and their experiences rather than by a rehearsal of dates and events" underlies the work of British-Guyanese writer Fred D'Aguiar. ${ }^{6}$ His novel Feeding the Ghosts (1997) revisits the true story of the slave ship Zong, whose captain had over 130 living Africans thrown overboard in order to file an insurance claim for lost goods after an epidemic started destroying part of the cargo. Beyond the infamous historical event, Feeding the Ghosts offers a compelling description of the experience of the Middle Passage from the captives' point view. D'Aguiar's book is as important to literature as Smallwood's is to history. Indeed, if methodological reasons explain why the captives' subjective experience of the Middle Passage long remained outside the field of historiography, it is also, perhaps more surprisingly, largely absent from literary texts: from slave narratives, which strikingly often skip over the voyage, to contemporary novels, which use it mainly in symbolic and metaphorical ways, the Middle Passage has rarely been explored for itself or been the object of extensive and detailed representations in African diasporic literature. ${ }^{7}$ The reasons for this elusion or oblique treatment are no doubt complex, but it may be that the Middle Passage somehow resists narrative form. As Paul Gilroy intimates, because of its traditionally mimetic quality the novel may be the genre that most seriously bears the "scepticism about the value of trying to revisit the sites of ineffable terror in the imagination."

Similar political and ethical issues no doubt account for its scarce representation in film. The sentimentalist and aestheticizing treatment of the subject in Steven Spielberg's Amistad (1997) has, perhaps, demonstrated the limits and dangers of filmic representations that "aestheticise the suffering of the victims in a way that instrumentalises their plight for 'sensational,' both literally and figuratively, or cathartic effect." 9 Passage $d u$ milieu (2000), by Martinican filmmaker Guy Deslauriers, stands, therefore, as a notable exception. Often considered as the "anti-Amistad," it succeeds precisely through its unspectacular treatment of the subject. ${ }^{10}$ In stark contrast to the pathos and drama of Spielberg's rendition of the voyage, this dialogue-free "docu-fiction" conveys the captives' experience through its painfully slow rhythm, its repetitive plot and frames, 
and the ponderous and dispassionate tone of the voice-over narrator. ${ }^{11}$ Much of the film's power also lies in the fact that, rather than focus on a particular - and particularly violent - historical event, as Spielberg and D'Aguiar do, it depicts the everyday violence that rules aboard a generic slave ship on an ordinary voyage.

All produced in the last two decades, Smallwood's Saltwater Slavery, D'Aguiar's Feeding the Ghosts, and Deslauriers's Passage du milieu are thus significant contributions to the fields of historiography, fiction, and film, insofar as they focus specifically on the Middle Passage as experience, which they attempt to represent from the captives' own point of view. These three texts, in the words of their authors, respond to the necessity to redefine the Middle Passage as a "human adventure" (Deslauriers), to re-invoke "the lives of the lost" (D'Aguiar) and bring them "to life as subjects in American social history" (Smallwood). ${ }^{12}$ Beyond their novel approach and their individual poetic, aesthetic, and scholarly qualities, what is most striking about these three texts, however, is that they largely succeed in their stated objective by using a figure that seems antithetical to the very notions of humanity, subjectivity, and agency: the living dead. In literary and cultural studies, "living dead" is often used - without definition, and often interchangeably with the term "undead" - as a generic term and it has been applied to a variety of creatures in popular culture, from ghouls and vampires to ghosts and zombies. Rather than an umbrella term, I use it here in its more basic, literal sense as an oxymoron: if the ghastly quality of the figure powerfully conveys the life-threatening conditions of the slave ship's hold, its dual character, as a creature that is both alive and dead, neither alive nor dead, allows Smallwood, D'Aguiar, and Deslauriers to explore the various and complex ways in which the Middle Passage challenges, troubles, sometimes utterly reconfigures, the boundaries of life and death.

Saltwater Slavery, Feeding the Ghosts, and Passage du milieu all depict the slave ship at sea as a "limbo [...] that could sustain neither life nor death" (Smallwood 145). The liminal and, according to African cosmographies, impossible time-space of the Atlantic had profoundly disorienting and alienating effects on the captives; it made them question both their capacity to live in such dire conditions and to die honorably and take their traditional place as ancestors in the community. These are two main aspects of the Middle Passage that Smallwood analyzes in a chapter titled "The Living Dead aboard the Slave Ship at Sea"; her historical and anthropological account sheds useful light on D'Aguiar's and Deslauriers's fictional narratives, which represent the captives' experience in very similar terms.

The living dead is also key to the three texts' exploration of the power dynamics at work in what Gilroy described as the "living, micro-cultural, micro-political system in motion" that was, the slave ship, and of the conflicting narratives it produced. ${ }^{13}$ As it introduced the African captives to the social order, the economy of terror and violence, the restriction of movement, and forced labor that would be their daily reality in the "New World," the slave ship constituted an important time-space in their transformation from captives into slaves. Their descent into this "hollow place," as Olaudah Equiano called it, marked the beginning of their marginalization from social life, the violent encounter with what Orlando Patterson has identified as the primary constituent element of slavery: social death. ${ }^{14}$ "Alienated from all 'rights' or claims of birth," Patterson explains, the slave "ceased to belong in his [sic] own right to any legitimate social order"; existing only through and for his master, his existence was a form of "living death."15

Patterson's notion of social death allows him to produce a generic definition of slavery that Smallwood explicitly draws on and that is also particularly useful for reading D'Aguiar's and Deslauriers's depictions of the slavers' definition and treatment of the 
captives. However, compared to other forms of slavery Patterson examines in his encyclopedic study, modern Atlantic slavery was particular in that it rested on a global, capitalist system which, before it produced slaves, produced commodities that were marketed, bought, and transported. As Smallwood demonstrates, it is precisely on the slave ship that the captives were turned into commodities, as their transportation required that they be treated as "commensurable units" that could be stowed in the hold like other kinds of goods (Smallwood 82). In this highly rationalized enterprise, the slavers had to determine, "the boundaries of the middle ground between life and death where human commodification was possible" (34). In effect redefining these boundaries, the slavers turned the captives into living dead as they treated living human beings like inanimate objects.

In the way it conveys the complete dehumanization and objectification of the Africans, the living dead merges here with the zombi, a figure that indeed appears in African diasporic culture as an avatar of the slave. Of West African origin but now more generally associated with Caribbean, more particularly Haitian, culture, the zombi initially designates a dead person brought to "that misty zone which divides life from death" by a bokor or houngan, a master for whom it must work or perform certain tasks. ${ }^{16}$ Dispossessed of its mind and subjectivity, it is "a thingified non-person reduced to its productive capacity," an animated dead whose only social utility is raw labor. ${ }^{17}$ If it seems a monstrous figure, the zombi is the result of alienation rather than the essence of otherness; its monstrosity therefore does not pertain to an intrinsic characteristic but points at the monstrosity of the forces that created it - the slavers, the slave trade, and slavery. Raising crucial questions about definitions and the power dynamics that underwrite them, the zombi/living dead thus allows Smallwood, D'Aguiar, and Deslauriers to, paradoxically, (re)humanize the slaves. ${ }^{18}$

If the living dead and the zombi are apt tropes for the social death and the dehumanizing and commodifying processes that the Middle Passage initiates, none of the texts I examine here portrays the Africans as the mere victims of these conditions. As Vincent Brown reminds us, Patterson's concept of social death does not "describe the lived experiences of the enslaved," but rather constitutes "a theoretical abstraction" that aims to "reveal the essence of slavery in an ideal-type slave." 19 Therefore, from the captives' point of view social death does not constitute an inescapable condition, but rather represents "a compelling threat" that generates a "politics of survival." 20 The living dead holds in tension - without ever resolving them - these opposite pulls. On the one hand, it seems to endorse the slavers' definition, which identifies the slaves as socially dead or as good as dead. On the other, it also subverts it for it is, after all, not fully dead; the part of life it contains suggests the possibility - however difficultly and painfully realized - of resistance, the captives' relentless efforts not only to survive but also to affirm their lives as human subjects. ${ }^{21}$ In encapsulating both the threat of social death and the life-affirming acts and practices that this threat compels, the living dead allows Smallwood, D'Aguiar, and Deslauriers to navigate a middle course between what Brown identifies as an unduly pessimistic and ultimately disempowering narrative that "pathologizes" and victimizes the captives and an overly celebratory one that fails to "account for the dislocations, physical violations, and cosmic crises" that enslavement inflicted on the captives. ${ }^{22}$

\section{Taken alive and treated like dead}

In The History of the Rise, Progress and Accomplishment of the Abolition of the African Slave Trade by the British Parliament (1839), Thomas Clarkson often conveys the 
horrors of slavery by describing at length the Africans' situation and inviting his readers to imagine themselves in their place. When he comes to the subject of the Middle Passage, however, he admits that "as far as this part of the evil is concerned," he is "at a loss to describe it." 23 Later in his History, however, the abolitionist praises an engraving that, better than any verbal description, speaks "in a language which [is] at once intelligible and irresistible." ${ }^{24}$ This "happy invention," originally produced in 1788 by the Plymouth chapter of the Society for Effecting the Abolition of the Slave Trade, is a plan of the lower deck of the slave ship Brooks, with 450 Africans tightly packed in four sections, for girls, women, boys, and men. ${ }^{25}$ Viewed from an overhead perspective, the hull of ship is shaped like a coffin, and the hundreds of neatly arranged, still figures of the slaves look like so many corpses. The text that accompanies the plan details the dimensions of the space allotted to each man, woman, and child, further emphasizing the sense of confinement. In a later version of the print, an additional paragraph reinforces the association between the slave ship and a coffin by describing the captives as being "reduced nearly to the state of being buried alive." 26

Today commonly known as "Description of a Slave Ship," the print in its various versions was, according to Clarkson, "instrumental in serving the cause of the injured Africans." ${ }^{27}$ Yet in their attempt to imprint upon their (white) viewers' minds the horrors inflicted upon the Africans, the abolitionists here in effect only further alienated them: while the print's simple black-and-white design powerfully, though economically, captures the claustrophobic atmosphere of the tightly packed hold, it also drowns the captives' individuality in a mass of hundreds of identical figures, visually and symbolically erasing their subjectivity by locking them in the passive role of helpless, silent, and anonymous victims. Marcus Wood contends that one of the reasons for the image's singular power is that "it was the only eighteenth-century representation of the middle passage that took one not only on board, but inside the hold of, a slave ship." 28 Yet "Description of a Slave Ship" does in fact not so much situate us inside the hold as offer us an external, schematic, and almost scientific cross-section view. The design was, after all, based on actual charts showing the dimensions of a ship's decks that captains used as instructions for effective packing. ${ }^{29}$ Destined to white liberal humanists, the print no doubt "seemed to make an instantaneous impression of horror upon all who saw it," but it did so by leaving them in the safe position of, as Clarkson himself puts it, "spectators." 30

This is also the position D'Aguiar assigns to us in the prologue to Feeding the Ghosts, which poetically evokes the jettisoning of 132 living Africans. Like "Description of a Slave Ship," the scene certainly inspires horror, but it also emphasizes the anonymity and powerlessness of the victims, who are depicted as bodies and are then textually fragmented into arms and legs, wounds, skin, and bones as they are dissected by the sea. The beauty of D'Aguiar's language, which describes the sea change that turns those once living bodies into sculptures of rock, shaped by salt and howling breath carried by wind, leaves us in uncomfortable awe. This effect is not unlike that produced by J.M.W. Turner's sublime use of color in Slavers Throwing Overboard the Dead and Dying, Typhon Coming On (1840) - a painting that was allegedly also inspired by the story of the Zong and that I think D'Aguiar invokes here. Here too, as Ian Baucom notes, "[w]e stand as spectators before it, not as witnesses in it." 31

After the prologue, the tone and perspective shift as the narrative focalizes on the crew of the Zong. Starting in medias res, as the captain is pondering how to expose to the sailors his plan to throw the sick but living cargo overboard in order to secure profit from the 
voyage, the first chapter introduces the Africans in terms reminiscent not only of the rhetoric and iconography of "Description of a Slave Ship" but also of Patterson's definition of slavery as social death. "[B]uried deep below deck," the captives appear to be already dead, inhabiting a kind of underworld clearly separated from the lively domain of the crew bustling about on the deck. ${ }^{32}$ The hold is described as a "cavern," a "dungeon" (21), a hell so dark, hot, and airless that the sailors resent entering it and drink the air avidly when coming back into the open. The Africans' cries, sounding like the wails of tormented souls, barely seep through the hatch and fail to reach the ears of the seamen. It is unclear whether the crew do not hear the sound because it is drowned in the ordinary hubbub of the creaking ship and roaring sea, or whether it has become too much a "part of the whole, all-encompassing fabric of routine" (10) for them to even notice it. In any case, the indifference that meets the distress of the captives and their relegation to another, marginal space suggests that they have "no socially recognized existence outside of [their] master." They are quite clearly, in Patterson's terms, "social nonperson[s]."33

While the beginning of Feeding the Ghosts situates us among the sailors and keeps the captives invisible below decks, Passage $d u$ milieu is, according to its director, "a narrative from the hold." 34 In contrast to the partial view offered by historical documents, which "are always the gaze of the Other upon the hold," Deslauriers opts for a subjective camera that places us amid the Africans. ${ }^{35}$ Yet various visual effects maintain a significant distance from the captives: we are among them, yet strangely not of them. For instance, the movement of the ship on the rolling sea is suggested by the actors' swaying to and fro while the camera remains steady; the captives' rocking thus seems exaggerated, even as we are reminded that we are safely on ground, watching a film spectators indeed. ${ }^{36}$ Although the Africans are individuals with recognizable features, their impenetrable gaze and expressionless faces estrange them, as we are unable to decipher their feelings and thoughts. A striking exception to this general impassivity which looks strangely close to passivity - occurs when the ship sets sail and the captives realize that they are leaving Africa. The narrator describes the "groan" that rises in the hold, and we see their agitation as they apparently start screaming and banging their chains in despair. ${ }^{37}$ Yet if we hear the clanking of the fetters, the creaking of the ship, and the wind rushing in the sails, no sound escapes the captives' wide open mouths. In fact, with the exception of the narrator - who, significantly, is actually dead as he speaks to us - the captives in Passage du milieu never utter a sound. Whereas D'Aguiar conveys the slaves' social death by describing their "just audible" (10) but unheard cries, Deslauriers shows the captives as literally voiceless.

That the living have no more social and symbolic power and existence than the dead becomes even more evident in both texts when external circumstances put the cargo and crew at risk. When the winds die down and leave Deslauriers's unnamed ship immobilized mid-Atlantic, making water and food scarce resources, the crew start throwing overboard "[f]irst, the dying, then the ill and the enfeebled, and finally anyone else." The repetition of scenes showing the bodies being tossed over or squeezed through the ropes is nauseating, but the narrator's calm evocation of the jettisoning suggests it is a measure of necessity: African lives are insignificant when the crew's survival is at stake. D'Aguiar, on the other hand, exposes the particularly perverse economic rationale behind the historical mass killing that took place aboard the Zong, in which the notion of necessity was instrumentalized in the name of profit: the captain knows that if the Africans die of natural death - and sickness is considered as natural death - their loss will fall on the investors and will therefore affect the officers and crew's profit, but the 
underwriters of the Zong will have to pay for those that were lost as part of "a necessary measure to preserve the remainder of the cargo" (13). In other words, dead stock thrown overboard is simply lost; living stock thrown overboard is worth substantial financial compensation. Systematic jettisoning, the captain explains to his crew, is therefore the only way for them all to ensure profit from the voyage. While from a legal and economic point of view it is crucial that the slaves be thrown overboard alive rather than after they have died of sickness, from a moral point of view it clearly does not make a difference to the captain: in the end, the living and the dead are all mere strokes in his ledger. When he orders his first mate to select the "severest cases" (20) and bring them on the deck in order to dispose of them, the phrase that qualifies the captives merely shifts from "already dead" to "as good as dead" (124). In showing how the slavers define the living as dead before they actually pass away or are killed, D'Aguiar demonstrates that they do not only have a claim on the slaves' lives, nor do they merely have the right of life and death over those they own: they also have the power to fix and shift, according to their (economic) interests, the very line between life and death.

As Smallwood points out, however, "[t]he slave ship at sea produced two competing narratives of the experience of the transatlantic voyage." To this dominant, European narrative that depicts the captives as socially dead, deprived of independent will and agency, is opposed another: that of the captives themselves, and of their "persistent and often lonely attempts [...] to continue to function as subjective beings" (122). It is this second narrative, a historically largely unrecorded one, that Smallwood attempts to retrieve in Saltwater Slavery, by making historical sources speak in different ways. It is also the story that Feeding the Ghosts and Passage du milieu tell, the former through shifting narrative perspectives and the latter through, in large part, the voice-over narrator. In all three texts, the figure of the living dead serves to articulate the captives' experience of the Middle Passage as a profoundly disorienting and alienating one, as it captures how it makes them physically and metaphysically navigate between life and death.

\title{
In limbo
}

Shortly after the first two captives have been thrown overboard by the crew of the Zong, the narrator of D'Aguiar's Feeding the Ghosts notes a change in the wind:

\begin{abstract}
Now the wind intensified. Before, it was merely playing in the sails and rigging, in the sleeves, trouser-legs and shirts of the men. Now it has found a voice that was a hum around the mainmast and whistled through the ship's rigging and rose to a howl, drowning out rain, sea and the distress that rose from below, putting in its place those very voices locked up in the hull, up on to the deck, up into the rigging, up among the sails and all around the ship, in a chorus of lamentation from which there was no hiding place, no door to be slammed, no hatch barred and no stopper coarse enough to protect the ears. (25-26)
\end{abstract}

D'Aguiar often uses the weather and its sudden changes to highlight the dramatic events taking place aboard the Zong. But what we see here is more than pathetic fallacy. D'Aguiar is not merely attributing human traits to the wind by giving it a voice to mourn the loss of the two Africans; nor is this voice the wind has found only that of the slaves locked in the hold lamenting the disappearance of those who were "taken alive and treated like dead" (27). As it soars up on the deck and in the sails and hovers all over the ship, this "chorus of lamentation" also contains the voices of those who just disappeared in the waters of the Atlantic. This is confirmed when the narrator then describes the 
Africans' anguish over the fate of the two men and, by extension, of their own probable fate: "what would become of their bones?" the living wonder; "They would lie in unsanctified ground, ground untrodden by any ancestor, not laid to rest but left in limbo" (37). The narrator of Passage du milieu voices the same belief as the crew "toss [the Africans'] bodies into the sea without any sort of funeral." ${ }^{38}$ Will their souls "have to err eternally"? The question is made all the more poignant because, as we discover near the end of the film, the narrator was himself the victim of such unceremonious jettisoning. Killed by the crew as the ship was approaching American shores, his voice has come to us all along from "the bottom of the ocean." The fact that he is telling his story from the "other shore of time" suggests that even at the close of the twentieth century he is not yet at rest. 39

What D'Aguiar and Deslauriers's respective narrative strategies dramatize is a reality that Smallwood's historical and anthropological account largely documents. Whereas for the slavers the death of a captive marked a simple "departure from this life," as one captain's journal accounts, for the Africans themselves "[d]eath represented not just a discrete event but rather a shift in social relations that had wide reverberations" (139), for the dead as much as for the living. In the absence of the mourning ritual and internment that traditionally ensured the successful migration of the deceased's soul to the realm of ancestors, the dead found themselves "trapped in a time-space regime in which they were unable fully to die" (152). The kinsmen of the deceased - whether they were on board the ship or in Africa - also suffered from these unfulfilled deaths, as they were thereby deprived of "a thread of the special power and protection only ancestral members of the community could provide" (141). As for the survivors who witnessed the departure and disposal of their fellow captives, they had to bear the burden of their wandering souls, "the cumulative weight of these deaths that remained unresolved" (152). The trope of the living dead, in this instance, serves to explain an anomaly caused by the Atlantic slave trade in the context of societies in which kinship and the presence of ancestors and their relationship with the living played a central role in the social and symbolic orders.

Smallwood identifies the social and spiritual crisis that death at sea constituted as perhaps "the most abject experience of the captives' Atlantic crossing" (152). As her book amply demonstrates, however, this is only one aspect of the metaphysical violence that the Middle Passage exerted on the captives and that menaced them with living death. Her evocation of the slave ship at sea as a "limbo" does not only concern the way the Middle Passage challenged the captives' conception of death, but it also suggests its disruptive effects on their definition of life. Trapped mid-Atlantic for several weeks or months, the Africans were utterly disoriented: they found themselves confined on a ship that was always in motion yet always appeared to be in the same place on the infinite sea, suspended in a time that seemed to stand still and could not be measured in any habitual way. Moreover, "the very habitat of the ship - the open sea - challenged African cosmographies, for the landless realm of the deep ocean did not figure in precolonial West African societies as a domain of human (as opposed to divine) activity." As a place where "life can be lived at sea," the slave ship thus represented "an oxymoron" for the captives (Smallwood 124).

Deslauriers and D'Aguiar both show this disorientation but, given their respective media, convey it in different ways. The narrator of Passage du milieu notes the Africans' inability to keep track of time from down in the hold, even to tell day from night in a darkness that is "as dazzling as the sun." However, more importantly, the film also succeeds in conveying the captives' experience by visually and structurally disorienting 
us. Its excessively slow rhythm, supported by a repetitive soundtrack, creates a sense of dullness that reproduces the captives' experience of the voyage as interminable. This is visually confirmed by the recurring aerial shots of the ship forever sailing on an apparently infinite expanse of water. Visual and textual repetitions also emphasize the routine violence that characterizes the journey: the seemingly endless jettisoning, the forced dances on deck for exercise, the "lecherous sailors" who nightly abuse the women and young girls all contribute to our impression that every day is just more of the same, never-ending nightmare. This impression is reinforced by slow fade-outs, which look as if we were, with the captives, closing our eyes on one scene of horror only to wake up again to yet another identical one. Time and space merge as the point of origin (Africa) and the destination ("the other shore") are conceived in terms of past and future - the Atlantic becomes an impossible intermediary space with no beginning or end that prevents the captives from seeing "further than the horizon of the present." Unable to think about their past at home or to foresee an end to the journey, they are locked in an eternal present that is equally unthinkable.

What Passage du milieu reveals is the collective, general experience of the Middle Passage. In a sense, the absence of individuated characters contributes to our own disorientation: we find ourselves vainly looking for the voice-over narrator among the captives, in order to be able to focus our attention and sympathy. ${ }^{40}$ Deslauriers's strategy here contrasts not only with Spielberg's singular and heroic portrayal of Cinqué but also with D'Aguiar's use of a protagonist, Mintah, which largely drives the action and focalizes the narrative. ${ }^{41}$ Thrown overboard not because she is sick but because she speaks out - in English - against the massacre, Mintah manages to grab a rope dangling from the ship and climb back on board. While she is all alone in the storeroom in which she has found refuge, the young woman is more disoriented and confused than she ever was in the hold, for she does not even have the comforting presence of her fellow captives to anchor her sense of self. On this ship that is "going nowhere," Mintah thinks, "[t]ime runs on the spot, neither backwards nor forwards" (199). ${ }^{42}$ In a desperate effort to disable the devastating power of the sea, she tries to give it the familiar features of her African homeland, seeing on its waves and troughs the benign shapes of hills and valleys, but it constantly shifts shape and conspires with the slavers to keep her doubly captive. In terms uncannily similar to Smallwood's, she evokes life at sea as a paradox: "A life on water was no life to live, just an in-between life, a suspended life, a life in abeyance, until land presented itself and enabled that life to resume" (61). As she finds herself thus trapped in limbo, "between [her] life" (199), she even comes to doubt that she is truly alive. D'Aguiar's portrayal of Mintah as a living dead effectively translates her subjective experience of the sea - both of nearly dying in the sea and of living at sea - and the way that experience shatters her definitions of life and death and her sense of her own condition.

Mintah's sense of self is further disrupted by her progressive dispossession of her own body, which "belongs to everyone but [her]" (200): the psychological as well as physical violence exerted by the sea, the Zong, and the crew leads her to envisage her body as somehow alien from her, not only beyond her control but even an instrument that turns against her. What Mintah evokes here is her fear of being turned into a mere object at the hands of the slavers. Significantly, according to Smallwood this is precisely what took place aboard the slave ship. In her examination of the journey that transforms "African captives" into "American slaves," the historian explains that it was on the slave ship that the major phase of this transformation took place, as they were turned into the 
intermediary status of "Atlantic commodities." This process already began on African shores, when the captives were first put in fetters, locked up in barracoons, and then sold to European slavers: stripped of their clothes, their names, all the "markers of their social existence" (60), they were divested of everything that identified them as people. But it was on the slave ship itself that they were fully dehumanized and objectified; they "became, for the purpose of transatlantic shipment, mere physical units that could be arranged and molded at will - whether folded together spoonlike in rows or flattened side by side in a plane" (68). The crux of the matter was to turn living human beings into mere pieces of cargo that could be transported alongside inanimate goods without extinguishing their lives.

By turning captives into commodities, the Middle Passage produced the slavers' "desired object: an African body fully alienated and available for exploitation in the American marketplace" (122). Smallwood's description of the commodified captive as a creature reduced to its most basic bodily functions and emptied of all the social, psychological, and spiritual components that make up the self is strikingly evocative of the zombi: a body without mind, personality, memory, or desire, an empty husk that exists only as a source of labor under the control of the master. Mintah evokes the impact of the voyage and of her treatment aboard the Zong in strikingly similar terms, as she pictures herself as a walking dead: "Unless I get [my body] back to land I will die in it even as it walks with me. I will be dead inside it. My body will set foot on land, and I will be inside unable to see this land since I will have died inside that body, killed by it" (200-201). It is significant, however, that the state she describes here is not her actual condition but a prospect - what will befall her if she cannot resist the alienating power of the slave ship at sea. What actually happens to her, although it may seem to be the same process, takes a significantly different form.

After a failed attempt at instigating an insurrection aboard the Zong, Mintah is kept tied on the deck with the men who followed her and forced to witness the incessant jettisoning of her fellow captives. Traumatized by the horror of the scene and her own powerlessness, she eventually falls into a state of numbness that has all appearances of living death, yet the process is not actually one of zombification, for her transformation does not occur in the idiom of death but of wood, an element that has been her ally throughout the voyage, literally saving her from the sea and giving her a sense of stability and a point of reference against disorientation. This suggests that although her transformation is a consequence of the psychological and physical abuse she was subjected to, it is somehow voluntary: it is a way for her to temporarily escape the pain and the horror of the ongoing events and to protect herself from her body until she can "get it back to land," where "it will recognise [her] again as a part of it" (200). This is indeed what happens as the Zong approaches American shores: slowly emerging from her torpor, she first recovers her body, then her subjectivity, and, finally, her name, as she slowly transforms back from "a plank of wood" to "bendable wood," to "living wood. Wood breathing," and to, finally, "Mintah" (134).

An equally attentive look at Passage $d u$ milieu shows a similar ambiguity in the depiction of the captives' condition. The narrator also describes the voyage as a process of slow "mortification" destined to turn the captives into walking dead fit for their new existence as laboring bodies. But in preparing the captives for slavery, the slave ship also prepares them to survive under its terrible conditions: the journey is like a vaccination that leaves the captives faint but also gives them, "paradoxically enough, the force needed to endure the hell of plantation life." Among the strategies of endurance that the captives 
develop, one appears similar to Mintah's, as they "gradually withdraw into themselves, to where they no longer feel the sailors' whips" and "barricade" their minds against all consciousness of their present situation. This casts a different light on their otherwise disturbing impassivity, which thus appears as a blank mask protecting an interior life, a life made accessible to us through the narrator's words and the images he conjures. The way Passage du milieu often visually unsettles our sense of whether the captives are actually alive or dead seems to confirm this reading: the painfully long shots focusing on the Africans' still bodies crammed in the hold show them as immobile and apparently lifeless or at the very least apathetic, until they suddenly stir or open their eyes and look straight at the camera, as if to accuse us of too hastily considering them as dead, or dead inside.

A similarly ambivalent depiction of the captives as both conditioned by and responding to the violation and dislocation caused by the Middle Passage appears in Smallwood, D'Aguiar, and Deslauriers's treatment of another important aspect of social death - what Patterson identifies as "natal alienation." According to Patterson, what made slaves "the ideal human tool" was the fact that they were "perfectly flexible, unattached, and deracinated":

It was this alienation of the slave from all formal, legally enforceable ties of 'blood,' and from any attachment to groups or localities other than those chosen for him by the master, that gave the relation of slavery its peculiar value to the master. ${ }^{43}$

Building on Patterson's general conceptualization of slavery, Smallwood notes that in the case of the Atlantic trade the slaves did not only suffer this constitutive element of social death but were in fact literally dead to their communities: since none of those who had disappeared into Atlantic slavery ever returned, they were commonly assumed to have been killed or even eaten by the Europeans. Other historians have noted that for many West African communities the Atlantic lay as a literal "boundary between the lands of the living and the domain of the dead," whose crossing "represented a premature and unnatural death." ${ }^{\text {As }}$ they thus passed "beyond the physical and metaphysical reach of kin," the captives faced what Smallwood describes as "the perpetual purgatory of virtual kinlessness" (61). The sea thus represented both literal and symbolic death, and even those who were not physically thrown into its monstrous depths were metaphysically threatened with living death.

Feeding the Ghosts and Passage du milieu offer poignant evocations of natal alienation, as well as of the Africans' desperate attempts to cope with it. D'Aguiar explores at length the effects of the sea's "limitless capacity to swallow love, slaves, ships, memories." For the Africans, the sea is "nowhere" not only in geographical but also in social terms since home and love are behind them and what lies ahead is a land where they will "be lost forever but not dead, lost but never to be found" (27). The past is both a source of comfort and a source of grief, and they hesitate between conjuring and burying it. Mintah at first describes her memory as a storeroom full of supplies for her sustenance, but what she retrieves from it is in the end not "a balanced diet [...] of recall" (61) but always the same items, now going stale and offering no real nourishment. Deslauriers shows an equally complex and ambivalent link to home, kin, and past. "We are all alone, without ancestors, without totems and without names," the narrator laments, while the aerial views of the slave ship irremediably sailing forward visually confirm the captives' growing isolation. The depiction of the voyage is regularly interrupted by 
scenes in Africa; whether they depict a carefree, precolonial, preslavery time, or life going on in the present oblivious of those who were sold away and are gone forever, these scenes suggest not only the disjunction between daily life "at home" and the present - as well as future - reality of the captives, but also the complete and definitive loss of their communities. But these scenes could alternatively be interpreted as visual evocations of the captives' memories of home, thus suggesting their striving against natal alienation. This unresolved ambiguity allows Deslauriers to suggest simultaneously the tragedy of natal alienation and the captives' resilience.

\section{The tomb and the womb}

The captives perhaps found some relief and strength in each other's presence - as well as, no doubt, discomfort in their inescapable proximity. But this could not much attenuate their social isolation. Indeed, the Africans constituted, as Smallwood puts it, "the antithesis of community" (101): as the slave ship filled up in several ports according to whatever stock was available on the coast markets, it brought together in "anomalous intimacies" individuals or small groups of very diverse social, cultural, and ethnic origins. In fact, what they had in common was precisely their isolation from their kin and community. The narrator of Passage du milieu says as much when he describes the people who have been brought together to share the cramped space of the hold:

They came from all four directions, almost all the coastal and inland peoples were represented. There were Ibos, Hausas, Fantis, Ashantis, Huedas, Yorubas, Wolofs from Senegambia. And from as far away as the cliffs of Bandiagara, an entire group of Dogons. There were also Mandinkas, Peuls, Bambaras.

And me.

Just another drop in the sea.

At this early stage, he emphasizes their cultural isolation not only with regard to their home communities but also to each other, and he even singles himself out in his isolation. The rest of the film, however, suggests how those individuals, "all foreigners to each other," are "soon to mingle and form a single people." It shows, for example, how they one day turn the "listless gesticulating" they are forced to perform on the deck for exercise into a "real dance" through which they call the spirits. As we hear the sound of African drums drown the "despicable tune" of the sailor's fiddle, the dancers all join in movements that they never learned to perform as a group but that, nevertheless, seem to naturally bring them together in a collective act of self-affirmation and defiance. Rather than reflect a common cultural tradition, the dance reveals the emergence of a new collective body. That the sailors recognize it as such is shown by the fear that dawns on them, a fear that the captives will later kindle by launching an insurrection.

Mintah also instigates a revolt on the Zong, taking advantage of the fact that the crew think her dead and of the freedom of movement this gives her on the ship. The plan fails and leads to Mintah's and her accomplices' capture, but it does succeed in giving the rebels something they had not known since they left Africa. As they are kept tied together on the deck, Mintah and the four men who followed her are bound by much more than their chains. Although they are mere strangers, they spontaneously initiate a "song of their own," an "anthem" (111) that gives them comfort and hope, as it competes with the roaring of the rain, the wind, and the sea, and helps them endure their fear, the cold, and 
the repeated blows from the crew. The memory of those hours spent in chains on the deck, which Mintah will relive in her dreams every night of her life, will be tied to the hope that slavery will one day come to an end, that Africa and America will finally be united in freedom, just as she now feels united with these men. That night, Mintah and her companions become "shipmates," a term captives used to call each other and that designated a form of "fictive kinship" (Smallwood 198) born of the shared experience of the Middle Passage.

What D'Aguiar, Deslauriers, and Smallwood suggest, then, is not only that the captives strive to retain the social and cultural life that their condition as captives and commodities threatened to dislocate; it is also that new forms of social and cultural life in fact emerge from this condition, that, as Brown puts it, they "make their cultural practices from the stuff of death and dissolution." ${ }^{45}$ In this they do not only challenge the common but now outdated conception of the Middle Passage as marking a clean break, constituting such a traumatic experience that it erased all memory of Africa and all trace of African culture - a view that has been debunked as one aspect of the "myth of the negro past" and denounced as "a fiction that has served several economic orders and their attendant ideologies." 46 By exposing the disruptive nature of the Middle Passage on all aspects of the captives' lives as well as death, they also eschew all simple views of "retentions" and "survivals" of African cultures. In showing how the social and cultural identities of the captives were shaped by the shared experience of the Middle Passage itself, they establish it in very concrete ways as a foundational - though traumatic - event.

This conception of the Middle Passage as the liminal space-time that marked the beginning of a new culture is reminiscent of earlier evocations by Caribbean writers and cultural critics. Building on Edward Kamau Brathwaite's evocation in The Arrivants of the limbo dance as a cultural practice born on the slave ship, Wilson Harris uses the limbo - in a deep play on words - as a way to theorize the development of a "new corpus of sensibility" that re-members African legacies and tribes in the New World. ${ }^{47}$ Re-enacting the captives' resistance, this "limbo imagination" becomes a "re-creative response" to symbolic and historical violence and domination in the Americas. ${ }^{48}$ In Poetics of Relation, Edouard Glissant evokes the Middle Passage in similar terms, as he pictures the slave ship's hold as:

a womb, a womb abyss. It generates the clamor of your protests; it also produces all the coming unanimity. Although you are alone in this suffering, you share in the unknown with others whom you have yet to know. This boat is your womb, a matrix, and yet it expels you. ${ }^{49}$

Like for any newborn, the delivery is painful and traumatic. But sharing the same womb, enduring together the experience of the abyss created a form of knowledge that, although unconscious, "served as the alluvium for [the] metamorphoses" that created what would come to be called the African diaspora. ${ }^{50}$ Like Brathwaite's and Harris's limbo and Glissant's womb abyss, the dual figure of the living dead signifies both the destructive and the creative nature of the Middle Passage. However, instead of emphasizing the space-time of transformation, as the womb abyss and the limbo both do, the living dead more forcefully conveys the impact of the experience on the people who endured it.

Unlike the limbo, moreover, which suggests a ritual of rebirth - as the dancers lower their body to pass under the pole and come to their full height again on the other side the living dead also complicates the conception of the Middle Passage as a linear movement from life (in Africa) through death (on the Atlantic) to rebirth (in America). 
As an oxymoron that holds life and death in constant tension rather than in sequence, the living dead compels us to think about what will become of the captives after the Middle Passage. Like Glissant's womb-boat, which is "pregnant with as many dead as living under sentence of death," so inhospitable that even those it delivers alive are doomed to a life of suffering, the living dead of the Middle Passage also pose the question that Hayden's poem only intimates in its opening and closing lines: ${ }^{51}$

Middle Passage:

voyage through death

to life upon these shores. ${ }^{52}$

What kind of life awaits those who survive the journey? Can the physical, metaphysical psychological, and social crisis that the Middle Passage produced be resolved by the end of the voyage and the landing in the "New World?" If social death is a constituent element of slavery, are the captives-become-slaves not doomed to remain living dead forever?

\section{Life upon these shores}

Smallwood, Deslauriers, and D'Aguiar offer different answers to those questions. If Deslauriers gives us a hint of what the slaves' existence will be like when the narrator evokes "the hell of plantation life," he leaves it to us to imagine what their story will be, for it lies outside the narrative of Passage du milieu. In suggesting that the captives would now embark on "a new passage," however, he clearly implied that the end of the journey did not mark the end of the nightmare, but the beginning of another, perhaps even more terrible ordeal. ${ }^{53}$ In the last chapter of Saltwater Slavery - titled "Life and Death in Diaspora" Smallwood is more precise about the ways in which "the death march continued on American soil" (193). Not only were many of those who reached their destination "near death" because of the ravages the voyage inflicted upon their bodies, but many would succumb in the first few years to overwork and infectious diseases. As for those who survived the period of seasoning, they would have to continue to endure, and find ways to counter, the social death and natal alienation that would condition their lives as "American slaves," to forever forestall "further descent into an endless purgatory" (189). Furthermore, the slaves "could never completely escape the saltwater, for even once an African captive's own middle passage had ended, the communities where that slave's life played out in the colonial Americas continued to be molded by the rhythm of ships returning to deposit still more bodies" (7). As the "traumatic echo" (202) of the Middle Passage reverberated throughout their existence, time seemed to stand still as it had on the Atlantic itself.

It is the latter two aspects, the continued threat of social death and the traumatic effects of the voyage that D'Aguiar explores in the second and third parts of Feeding the Ghosts. The first part of the novel ended with the Zong nearing Jamaican shores and Mintah returning to her senses and, significantly, affirming her subjectivity and aliveness again by repeating out loud, "I am Mintah" (134). In the second part of the novel, which relates the trial between the investors and the underwriters of the Zong, she all but disappears from the narrative. The Africans indeed have no role to play in the deliberation, which concerns only the financial consequences of the recent events. But her name and voice do come up during the proceedings, in the form of a notebook in which she related the massacre aboard the Zong while she was hiding in the storeroom, and which she entrusted to Simon, the cook's 
dim-witted but kind-hearted assistant. Her account, however, is quickly dismissed as having been "penned by a ghost" (169), a phrase that points out both Mintah's absence from court and the doubtful authorship of the document, which, the counsel for the investors contends, "a slave could not have written" (168). In rejecting her testimony, the court confirms that Mintah and her fellow captives - whether they survived the massacre or not legally still are nonpersons. And in ruling in favor of the investors, that is, in recognizing the captain's extreme measure as justified by necessity, it symbolically kills the victims a second time.

As a direct counterpoint to this reaffirmed definition of the slaves as socially dead, D'Aguiar gives the third part of the novel to Mintah. In making her the narrator of and agent in her own story, D'Aguiar works against the silencing and objectifying gestures and discourses that are intrinsic to the institution of slavery; but he thereby also exposes their inevitable and long-lasting effects on the slaves. Eschewing both heroism and victimhood, the story of Mintah in America is one of sustained life-affirming acts in an existence marred by death, bearing the physical and psychological marks of a traumatic experience. We thus learn how, against the prediction that she "would die and be buried" (205) on the Maryland plantation to which she was auctioned, she was in fact able to buy her own freedom with money she earned by teaching poor white children. Turning to teaching black children after her emancipation, she also helps slaves escape North; in her mind, the fugitives merge with the victims of the Zong, for whose each and every death she multiplies by two the number of people she guides to freedom. While her efforts to redeem the lives of the lost by securing freedom and education for the next generations demonstrate her struggle against natal alienation, she pays a bitter price for her actions: when rumors about her participation in the Underground Railroad start spreading, she is forced to abandon home, friends, and a lover, condemned to be alone and isolated again.

Moving to Jamaica - the first land she felt under her feet when she reached America in order "to put slavery behind [her] once and for all" (201), she finds herself again surrounded by the sea, a sea that was "spoiled" and "ruined" (219) for her and that only brings up painful memories. To protect herself and the dead from a sea that "possesses and never relinquishes [...] destroys but does not remember" (210), she starts carving little wooden figures, one for each of the 131 victims of the Zong. In the absence of her shipmates, who now exist only in her dreams, the figures become her kin. As her "progeny," they also stand for the descending lines that the Middle Passage severed, since her violent treatment aboard the Zong has made her body infertile and will not allow her to "be made into newer shapes of people" (210). Although she claims she "ha[s] always been free" (205), she remains a slave to the past: her obsessive wood-carving betrays her failure to integrate her traumatic memory into her "life's story." 54 She spends the rest of her days in the lonely but overwhelming company of the dead and devotes all her time to "assuag[ing] their hunger" (222).

In refusing his protagonist the happy ending offered by other - historical or fictional slave narratives, D'Aguiar concurs with Smallwood's conclusion to Saltwater Slavery: for those who survived it, the Middle Passage in fact "was perhaps the antithesis of a 'middle' passage, with all that phrase implies about a smooth, linear progression leading to a known end" (Smallwood 207). This is also what the end of Passage du milieu predicts: for the captives, the new land that appears at the end of the voyage is merely "where the end and the beginning meet up." But rather than ponder the aptness of the term Middle Passage, the three narratives I have examined here use the figure of the living dead to completely redefine it: on the one hand, the dual quality of the living dead 
imbues the adjective "middle" with more layers of meaning, unpacking all the levels at which the "Middle Passage" constitutes an intermediary space-time; on the other hand, the forever irreconcilable nature of the oxymoron recasts this liminality as perpetual.

Ultimately, D'Aguiar and Deslauriers offer yet another reason for reappraising the term. If Smallwood, as a historian, must bring her narrative to some form of conclusion, Feeding the Ghosts and Passage du milieu both extend theirs with epilogues that suggest that the Middle Passage is anything but over. In the last pages of the novel, the Zong appears as much more than the historical ship whose fateful voyage became a cause célèbre in the eighteenth century and today figures in many history books about the slave trade. Shifting the narration from singular to plural form and from past to present tense, D'Aguiar places not only all the other victims of the Middle Passage throughout history aboard the Zong, but also all their descendants who have endured the legacy of slavery in the Atlantic world. The Zong, a mysteriously timeless - living dead? - narrator tells us, is on an "unending voyage." The death that took place aboard "remains unfinished because it recurs" (230), in other forms, other places, and other times. Deslauriers offers us a terrible example of such modern manifestations of the Middle Passage: it happened again, the living-dead narrator reminds us, as recently as 1992, at the time, ironically, of the 500 years' celebration of America's "discovery," when the crew of a cargo - presumably the MC Ruby, a Bahamian-flagged cargo ship bound for Le Havre - murdered and threw eight African stowaways into the Atlantic. Their bodies added to the road of bones that paves the bottom of the sea. Their souls joined the countless others, including the narrator himself, who "forever trouble the peace of the ocean." Ultimately, the living dead of the Middle Passage are also evidence that we still live in "the afterlife of slavery."

\section{Note on Contributor}

Joanne Chassot received her Ph.D. from the University of Lausanne, Switzerland, where she now works as a lecturer. She is currently preparing a book on the ghost trope in contemporary African diasporic literature. Her broader interests include postcolonial and queer studies and literature.

\section{Notes}

1. Hayden, "Middle Passage," 48, 54.

2. J. C. Miller, Way of Death, 314; Rediker, The Slave Ship, 274; and Smallwood, Saltwater Slavery, 137.

3. Klein, Middle Passage, xv.

4. Ibid., 251.

5. Smallwood, Saltwater Slavery, 137. Subsequent references to Saltwater Slavery will appear in textual parentheses.

6. Frías, "Building Bridges," 418.

7. Not that the Middle Passage does not feature prominently in African diasporic literature: its foundational importance and symbolic significance in the historical and cultural consciousness of the African diaspora make it a haunting presence in its literary production, appearing in countless allusions and images and serving as a referent for ruminations on roots and rootlessness, diasporic identity, racism, and violence and even modern forms of migration. For an overview of the major Anglophone narratives evoking the Middle Passage, see Binder, "Uses of Memory." For a study of autobiographical accounts in English by African-born slaves, see Handler, "Survivors of the Middle Passage."

8. Gilroy, The Black Atlantic, 218. 
9. Eckstein, "The Pitfalls of Picturing Atlantic Slavery," 76. Amistad, moreover, is mostly concerned with the legal battle that followed the historical slave rebellion aboard the Spanish ship, and therefore only pictures the voyage in a flashback scene during the slave protagonist's defense speech. Other films that feature the Middle Passage include Tay Garnett's Slave Ship (1937), Tamango (1958), directed by John Berry, and the first episodes of the TV mini-series Roots (1977), based on Alex Haley's saga. For a discussion of these films see Harms, "The Transatlantic Slave Trade in Cinema" and C. Miller, The French Atlantic Triangle, 179-245.

10. C. Miller, The French Atlantic Triangle, 381.

11. "Docu-fiction" is the term Deslauriers used to describe his film. Barlet, "Le point de vue des captifs."

12. Deslauriers, "Note d'intention" (my translation); Frías, "Building Bridges," 423; and Smallwood, Saltwater Slavery, 3.

13. Gilroy, The Black Atlantic, 4.

14. Equiano, Interesting Narrative, 57.

15. Patterson, Slavery and Social Death, 5, 8.

16. Métraux, Voodoo in Haiti, 282.

17. Glover, Haiti Unbound, 59.

18. In preferring the spelling "zombi" to the more common "zombie," I follow, among others, Alfred Métraux and Joan Dayan. In doing so, I also wish to distinguish the figure from the hordes of North American living dead that have invaded movie theaters, TV screens, and comic books since George Romero's popularization of the genre.

19. Brown, "Social Death and Political Life," 1233.

20. Ibid., 1240, 1246.

21. Kaiama Glover makes a similar argument about the zombi, in a reading that is largely at odds with the more traditional definition of the zombi as the pure victim of a definitive condition of living death. See Glover, Haiti Unbound, 59-60.

22. Brown, "Social Death and Political Life," 1236, 1244.

23. Clarkson, History, 1: 14.

24. Ibid., 2: 187.

25. Ibid., 111.

26. Quoted in Rediker, The Slave Ship, 315.

27. Clarkson, History, 2: 111.

28. Wood, Blind Memory, 36.

29. Finley, "Committed to Memory," 7.

30. Clarkson, History, 2: 187.

31. Baucom, Specters of the Atlantic, 292.

32. D'Aguiar, Feeding the Ghosts, 9. Subsequent references to the novel will appear in textual parentheses.

33. Patterson, Slavery and Social Death, 5.

34. Barlet, "Le point de vue des captifs" (my translation).

35. Ibid.

36. This starkly contrasts with the hectic movements of the camera in Amistad, whose dramatic effects are reinforced by the fact that most of the scenes in the hold are depicted as taking place during a thunderstorm, which only allows us to see the captives in lightning flashes.

37. Deslauriers, Passage du milieu. All quotations are from the English subtitles to the original French version.

38. D'Aguiar and Deslauriers both contrast the brutal jettisoning of the Africans - dead or alive with the ritual that accompanies the sea burial of the sailors. In Feeding the Ghosts, the naked and defenseless bodies of the Africans are thrown straight into the shark-infested waters, while the corpse of a dead crewman is wrapped in his hammock and ballasted with iron so that it will quickly sink. Before the body gently slides off a plank into the sea, the captain opens his Bible and pronounces the name of the dead sailor, whereas the deaths of the nameless slaves are recorded by mere strokes in his ledger. Passage du milieu shows a similar ritual performed for a sailor who died from the spreading epidemic, while the innumerable corpses of the Africans are silently squeezed through the ropes and disappear in the bubbling, reddening water.

39. The account of the voyage is framed by a prologue and an epilogue showing a child on some present-day Caribbean island. The narrator addresses this child, who "could not imagine the 
horrors [the sea's] waters have witnessed." His story is meant to instruct him about this submerged history.

40. By disallowing our identification of, and therefore with, individuated characters, Passage $d u$ milieu also suggests the captives' social disorientation: like us, the Africans who have thus been brought together in the slave ship's hold are all strangers; they have no or few familiar faces to find comfort in.

41. D'Aguiar explains his choice of a female protagonist as a "natural progression" from his previous works and as his desire to explore the particular historical silence that surrounds slave women. Frias, 422. In that respect, it is worth noting that despite its generic quality Deslauriers' narrative is presented primarily through a male point of view. Whereas the film repeatedly shows us the men's bodies in painfully long shots, we only see the female captives when the narrator mentions the sexual abuse they endure every night. The women are also associated with Africa, the nurturing mother who was raped and whose children were taken from her.

42. The novel also suggests that time does not only resist the Africans' habitual ways of measuring it, but is controlled by the slavers: during the three days at sea that the novel relates, time seems to be regulated by the strokes the captain makes in his ledger to account for the dead, and each day ends when he allows the killing to finally stop for the night.

43. Patterson, Slavery and Social Death, 337, 7.

44. J. C. Miller, Way of Death, 4; and Schuler, "Enslavement,"186.

45. Brown, "Social Death and Political Life," 1246.

46. Herskovits, The Myth of the Negro Past; and Gates, The Signifying Monkey, 4.

47. Harris, "History, Fable and Myth," 158.

48. Ibid., 160.

49. Glissant, Poetics of Relation, 6.

50. Ibid., 7.

51. Ibid., 6.

52. Hayden, "Middle Passage," 48, 54.

53. Barlet, "Le point de vue des captifs" (my translation).

54. Herman, Trauma and Recovery, 175, quoted in Smallwood, Saltwater Slavery, 206.

55. Hartman, Lose Your Mother, 7.

\section{References}

Barlet, Olivier. "Le point de vue des captifs. Entretien avec Guy Deslauriers." Africultures (1998). Accssed July 1, 2006. http://www.africultures.com/php/?nav=article\&no=4473.

Baucom, Ian. Specters of the Atlantic: Finance Capital, Slavery, and the Philosophy of History. Durham, NC: Duke University Press, 2005.

Berry, John, dir. Tamango. France and Italy: CEI Incom, 1958.

Binder, Wolfgang. "Uses of Memory: The Middle Passage in African American Literature." In Slavery in the Americas, edited by Wolfgang Binder, 539-564. Wurzburg: Konighausen, 1993.

Brathwaite, Edward Kamau. The Arrivants: A New World Trilogy. London: Oxford University Press, 1973.

Brown, Vincent. "Social Death and Political Life in the Study of Slavery." American Historical Review 114, no. 5 (2009): 1231-1249. doi:10.1086/ahr.114.5.1231.

Clarkson, Thomas. History of the Rise, Progress and Accomplishment of the Abolition of the African Slave Trade by the British Parliament. 2 vols. London: Longman, Hurst, Rees and Orme, 1808.

D'Aguiar, Fred. Feeding the Ghosts. London: Vintage, 1998.

Dayan, Joan. Haiti, History, and the Gods. Berkeley: University of California Press, 1998.

Deslauriers, Guy. "Note d'intention." Les Films du Raphia:Passage Du Milieu. Accessed July 22, 2014. http://www.raphia.fr/films/passage.html.

Deslauriers, Guy, dir. Passage Du Milieu. Paris: Kreol Productions, 2000.

Eckstein, Lars. "The Pitfalls of Picturing Atlantic Slavery: Steven Spielberg's Amistad vs Guy Deslauriers's The Middle Passage." Cultural Studies Review 14, no. 1 (2008): 72-84.

Equiano, Olaudah. The Interesting Narrative and Other Writings, edited and with an introduction by Vincent Carretta. New York: Penguin, 2003. 
Finley, Cheryl. "Committed to Memory: The Slave-Ship Icon and the Black-Atlantic Imagination." Chicago Art Journal 9 (Spring 1999): 2-21.

Frías, Maria. "'Building Bridges Back to the Past': An Interview with Fred D'Aguiar." Callaloo 25, no. 2 (Spring 2002): 418-425. http://www.jstor.org/stable/3300567.

Garnett, Tay, dir. Slave Ship. USA: Twentieth Century Fox, 1937.

Gates, Henry Louis, Jr. The Signifying Monkey: A Theory of African-American Literary Criticism. New York: Oxford University Press, 1989.

Gilroy, Paul. The Black Atlantic: Modernity and Double Consciousness. Cambridge, MA: Harvard University Press, 1993.

Glissant, Edouard. Poetics of Relation. Translated by Betsy Wing. Ann Arbor: University of Michigan Press, 1997.

Glover, Kaiama L. Haiti Unbound: A Spiralist Challenge to the Postcolonial Canon. Liverpool: Liverpool University Press, 2010.

Handler, Jerome S. "Survivors of the Middle Passage: Life Histories of Enslaved Africans in British America." Slavery \& Abolition 23, no. 1 (2002): 25-56.

Harms, Robert. "The Transatlantic Slave Trade in Cinema." In Black and White in Colour: African History on Screen, edited by Vivian Bickford-Smith and Richard Mendelsohn, 59-81. Athens: Ohio University Press, 2007.

Harris, Wilson. "History, Fable and Myth in the Caribbean and Guianas." In Selected Essays of Wilson Harris, edited by Andrew J. M. Bundy, 152-166. London: Routledge, 1999.

Hartman, Saidiya V. Lose Your Mother: A Journey Along the Atlantic Slave Route. New York: Farrar, Straus and Giroux, 2008.

Hayden, Robert E. "Middle Passage." In Collected Poems, edited by Frederick Glaysher, 48-53. New York: Liveright, 1985.

Herman, Judith Lewis. Trauma and Recovery: The Aftermath of Violence, from Domestic Abuse to Political Terror. New York: Basic Books, 1997.

Herskovits, Melville. The Myth of the Negro Past. Boston: Beacon Press, 1941 [1990].

Klein, Herbert S. The Middle Passage: Comparative Studies in the Atlantic Slave Trade. Princeton: Princeton University Press, 1978.

Métraux, Alfred. Voodoo in Haiti. New York: Schocken, 1972.

Miller, Christopher L. The French Atlantic Triangle: Literature and Culture of the Slave Trade. Durham, NC: Duke University Press, 2008.

Miller, Joseph C. Way of Death: Merchant Capitalism and the Angolan Slave Trade, 1730-1830. London: James Currey, 1988.

Patterson, Orlando. Slavery and Social Death: A Comparative Study. Cambridge, MA: Harvard University Press, 1982.

Rediker, Marcus. The Slave Ship: A Human History. New York: Viking, 2007.

Roots. The Triumph of an American Family. Produced by David Wolper. USA, 1977.

Schuler, Monica. "Enslavement, the Slave Voyage, and Astral and Aquatic Journeys." In Africa and the Americas: Interconnections during the Slave Trade, edited by José C. Curto and Renée Soulodre-LaFrance, 185-213. Trenton: Africa World Press, 2005.

Smallwood, Stephanie E. Saltwater Slavery: A Middle Passage from Africa to American Diaspora. Cambridge, MA: Harvard University Press, 2007.

Spielberg, Steven, dir. Amistad. USA: Dreamworks, 1997.

Wood, Marcus. Blind Memory: Visual Representations of Slavery in England and America, 17801865. New York: Routledge, 2000. 